\title{
EFFECTS OF PROSTAGLANDINS AND INDOMETHACIN ON NEUROMUSCULAR BLOCKING AGENTS
}

\author{
Gary E. Hill and K.C. WONG
}

\begin{abstract}
The effects on neuromuscular blockade by d-tubocurarine and succinylcholine of inhibition of prostaglandin.biosynthesis by indomethacin and of intra-arterial administration of prostoglandins $E_{2}$ and $F_{2}$ alpha, before and after inhibition of prostoglandin biosynthesis, were evaluated in the cat sciatic-tibialis preparation.

Non-specific inhibition of prostaglandin biosynthesis by indomethacin $3 \mathrm{mg} \cdot \mathrm{kg}^{-1}$ did not alter latency, maximal blockade or duration of neuromuscular blockade induced by $d-$ ubocurarine or succinylcholine.

Prostaglandin $\mathrm{E}_{2}$ antagonized twitch height depression by d-tubocurarine by an average of six per cent before and by 15 per cent after indomethacin, but potentiated the neuromuscular block of succinylcholine by an average of five per cent before and 60 per cent after indomethacin. Prostaglandin $F_{2}$ alpha antagonized d-tubocurarine neuromuscular block by an average of 10 per cent before and 18 per cent after indomethacin, but potentiated succinylcholine block by an average of four per cent before and 12 per cent after indomethacin.

These results suggest that non-specific inhibition of prostaglandin biosynthesis alone does not influence d-tubocurarine or succinylcholine induced neuromuscular blockades. However, both prostaglandin $E_{2}$ and $F_{2}$ alpha may induce transmitter release at the neuromuscular junction that may be enhanced by indomethacin, thus antagonizing the non-depolarizing blockade of d-tubocurarine and potentiating the depolarizing blockade of succinylcholine.
\end{abstract}

THE PROSTAGlandins are a group of compounds, named by von Euler in 1937, which possess varied pharmacological actions on the autonomic nervous system.' While the major area of investigation of prostaglandin action has been the cardiovascular system, little has been done on the effects of prostaglandins on the neuromuscular junction. The clinical use of non-steroidal anti-inflammatory agents such as aspirin, indomethacin and ibuprofen are common. They also inhibit the biosynthesis of prostaglandins. ${ }^{2}$ The present study evaluates the effects of two prostaglandins. $\mathrm{PGE}_{2}$ and $\mathrm{PGF}_{2 \text { alpha }}$ and a prostaglandin synthesis inhibitor, indomethacin, and the interaction of indomethacin with $\mathrm{PGE}_{2}$ or $\mathrm{PGF}_{2 \text { alpha }}$ on the neuromuscular blocking action of d-tubocurarine and succinylcholine.

\section{METHODS}

Forty cats of either sex weighing 2.6 to $5.1 \mathrm{~kg}$ were anaesthetized with intraperitoneal alpha-

Gary E. Hill, M.D., Assistant Professor of Anesthesiology (Present address: Saint Vincent Hospital, Billings, Montana); K.C. Wong, M.D., Ph.D., Professor and Chairman. Department of Anesthesiology; Associate Professor of Pharmacology. Department of Anesthesiology, University of Utah College of Medicine, 50 North Medical Drive, Salt Lake City, Utah, 84132, U.S.A.

Reprint request to K.C. Wong, M.D., Ph.D. chloralose $100 \mathrm{mg} \cdot \mathrm{kg}^{-1}$. Following intubation of the trachea mechanical ventilation with air maintained arterial $\mathrm{PCO}_{2}$ at 4.0 to $4.5 \mathrm{kPa}$ (30-35 torr) and $\mathrm{PO}_{2}$ at 11.3 to $12.7 \mathrm{kPa}$ (85-95 torr). The tendon of the right anterior tibialis muscle was dissected free, sectioned near the point of osseous attachment and connected to a Grass FT- 10 force displacement transducer. The right sciatic nerve was then sectioned and the distal peroneal nerve was isolated and supramaximal stimuli ( $1-8$ volts) of $0.5 \mathrm{msec}$ duration and $0.2 \mathrm{~Hz}$ were applied from a Grass stimulator, model $\$ 4 G$, through shielded platinum electrodes. The force of muscle contraction was recorded continuously on a Grass model 5 polygraph. The twitch tension exhibits only five per cent reduction from control over a three-hour period. The right femoral artery was exposed for intra-arterial drug administration. Body temperature was monitored and maintained at $36-38^{\circ} \mathrm{C}$. The left femoral artery was cannulated and connected to a Statham P23 $\mathrm{Db}$ arterial pressure transducer for continuous pressure and blood gas monitoring to ascertain cardiopulmonary stability.

Eight animals (Group 1) received an intravenous bolus injection of d-tubocurarine $0.2 \mathrm{mg} \cdot \mathrm{kg}^{-1}$, followed by a continuous infusion of d-tubocurarine $100 \mu \mathrm{g} / \mathrm{ml}$, through a Harvard infusion pump to produce 90 per cent twitch height depression. The 90 per cent twitch height

Canad. Anaesth. Soc. J., vol. 27, no. 2, March 1980 
TABLE I

Neuromuscular Blocking action of D-Tubocurarine and Succinylcholine Before and After lnhibition Of Prostaglandin Brosynthesis By lndomethacin (MEAN \pm S.E., $\mathrm{N}=4)^{*}$

\begin{tabular}{|c|c|c|c|c|c|c|}
\hline & \multicolumn{2}{|c|}{ Latcncy (sec) } & \multicolumn{2}{|c|}{$\begin{array}{l}\text { Percent of control } \\
\text { in twitch depression }\end{array}$} & \multicolumn{2}{|c|}{$\begin{array}{l}\text { Time (min) to } \\
\text { return to } 90 \% \\
\text { control }\end{array}$} \\
\hline & Bcfore & After & Before & After & Before & After \\
\hline \multicolumn{7}{|l|}{ Tubocurarine } \\
\hline $0.1 \mathrm{mg} \cdot \mathrm{kg}^{-1}$ & $\begin{array}{l}106 \\
\pm 10.6\end{array}$ & $\begin{array}{l}98 \\
\pm 8.7\end{array}$ & $\begin{array}{l}76 \\
\pm 4.5\end{array}$ & $\begin{array}{l}80 \\
\pm 2.7\end{array}$ & $\begin{array}{r}16.0 \\
+1.7\end{array}$ & $\begin{array}{r}16.4 \\
\pm 1.5\end{array}$ \\
\hline $0.2 \mathrm{mg} \cdot \mathrm{kg}^{-1}$ & $\begin{array}{r}61 \\
\pm 4.7\end{array}$ & $\begin{array}{r}62 \\
\pm 5.0\end{array}$ & $\begin{array}{r}96 \\
+3.8\end{array}$ & $\begin{array}{l}95 \\
\pm 1.5\end{array}$ & $\begin{array}{r}25.5 \\
\pm 2.5\end{array}$ & $\begin{array}{r}24.6 \\
\pm 2.7\end{array}$ \\
\hline \multicolumn{7}{|l|}{ Succinylcholine } \\
\hline $0.03 \mathrm{mg} \cdot \mathrm{kg}^{-1}$ & $\begin{array}{l}30 \\
\pm 3.0\end{array}$ & $\begin{array}{l}26 \\
\pm 2.2\end{array}$ & $\begin{array}{l}91 \\
\pm 2.7\end{array}$ & $\begin{array}{l}93 \\
\pm 1.2\end{array}$ & $\begin{array}{r}8.4 \\
\pm 0.8\end{array}$ & $\begin{array}{r}8.6 \\
+0.6\end{array}$ \\
\hline $0.06 \mathrm{mg} \cdot \mathrm{kg}^{-1}$ & $\begin{array}{l}12 \\
\pm 1.6\end{array}$ & $\begin{array}{l}13 \\
\pm 1.7\end{array}$ & $\begin{array}{l}100 \\
\pm 0\end{array}$ & $\begin{array}{r}100 \\
\pm 0\end{array}$ & $\begin{array}{r}15.4 \\
\pm 2.7\end{array}$ & $\begin{array}{r}16.1 \\
\pm 3.0\end{array}$ \\
\hline
\end{tabular}

* No significant differences between before and after data.

depression was maintained for 20 minutes before proceeding. A slow ( 5 minute) intra-arterial injection of either prostaglandin $\mathrm{E}_{2} 0.5 \mathrm{mg}\left(\mathrm{PGE}_{2}\right)$ (four animals), or $\mathrm{F}_{2 \text { alpha }} 0.5 \mathrm{mg}\left(\mathrm{PGF}_{2}\right.$ alpha) (four animals), was then given and the twitch height response was recorded. Another eight animals (Group 2) were treated the same as Group I, except that indomethacin $3 \mathrm{mg} \cdot \mathrm{kg}^{-1}$ was given intravenously one hour before administration of the same dose of $\mathrm{PGE}_{2}$ (four animals) or $\mathrm{PGF}_{2 \text { atpha }}$ (four animals). Indomethacin powder was dissolved by titration with $0.1 \mathrm{~N} \mathrm{Na} \mathrm{NO}_{3}$ after the method of Wilkerson and Glenn. ${ }^{3}$

Another eight animals (Group 3 ) received an intravenous bolus of succinylcholine 0.03 $0.1 \mathrm{mg} \cdot \mathrm{kg}^{-1}$ adequate to depress twitch tension 60 to 80 per cent. During maximal twitch tension depression, $0.5 \mathrm{mg}$ of either $\mathrm{PGE}_{2}$ (four

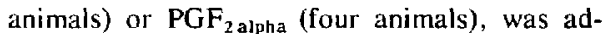
ministered intra-arterially and the twitch height response recorded as above. Group 4 of eight animals were treated and studied in the same manner as Group 3, except that indomethacin, $3 \mathrm{mg} \cdot \mathrm{kg}^{-1}$ was given intravenously one hour before administration of the prostaglandins.

In another eight animals (Group 5) four cats received d-tubocurare 0.1 and $0.2 \mathrm{mg} \cdot \mathrm{kg}^{-1}$ intravenously and four cats received succinylcholine, 0.03 and $0.06 \mathrm{mg} \cdot \mathrm{kg}^{-1}$ intravenously with the following parameters of neuromuscular function recorded: latency, maximal blockade obtained and time required for recovery to 90 per cent of control twitch tension. Methodology employed has been previously reported. ${ }^{4}$ A 45 - minute period was allowed between the two doses of the neuromuscular blocking agent. The same animal was studied one week later as described, except that indomethacin $3 \mathrm{mg} \cdot \mathrm{kg}^{-1}$ was given intravenousiy one hour before administration of the neuromuscular blocking agents.

Statistical significance was calculated using Student's t-test for paired or unpaired data. Differences with a probability of 0.05 or less were considered significant.

\section{RESULTS}

The latency period, maximum percent block obtained and time required to return to 90 per cent control twitch tension of neuromuscular blockade induced by d-tubocurarine and succinylcholine were not significantly altered by inhibition of prostaglandin biosynthesis induced by indomethacin (Table I). In these animals, the administration of the indomethacin vehicle, $(0.1 \mathrm{~N}$ $\mathrm{Na}_{2} \mathrm{CO}_{3}$ ) produced no change in the control twitch tension.

Prostaglandin $E_{2}$ antagonized neuromuscular blockade induced by d-tubocurarine by an average of 6 per cent $(p>0.05)$ before and 15 per cent $(p<0.05)$ after indomethacin but potentiated neuromuscular block induced by succinylcholine by an average of five per cent $(p>0.05)$ before and 10 per cent $(p<0.05)$ after indomethacin (Table II).

$\mathrm{PGF}_{2 \text { alpha }}$ antagonized neuromuscular blockade by d-tubocurarine by an average of $10 \mathrm{per}$ cent $(p<0.05)$ before and 18 per cent $(p<0.05)$ 
TABLE II

\begin{tabular}{|c|c|c|}
\hline \multicolumn{3}{|c|}{ 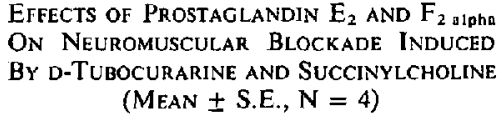 } \\
\hline \multicolumn{3}{|c|}{ Percent Antagonism of $\mathrm{d}$-Tubocurarine } \\
\hline $\begin{array}{l}\mathrm{PGE}_{2} \\
\mathrm{PGF}_{2 \text { alnha }}\end{array}$ & $\begin{array}{c}\text { Before } \\
\text { Indomethacin } \\
6 \pm 1 \\
10 \pm 1^{*}\end{array}$ & $\begin{array}{c}\text { After } \\
\text { Indomethacin } \\
15 \pm 3^{*} \\
18 \pm 2^{*}\end{array}$ \\
\hline \multicolumn{3}{|c|}{ Percent Potentiation of Succinylcholine } \\
\hline $\begin{array}{l}\mathrm{PGE}_{2} \\
\mathrm{PGF}_{2 \text { alona }}\end{array}$ & $\begin{array}{c}\text { Before } \\
\text { Indomethacin } \\
5 \pm 1 \\
4 \pm 1\end{array}$ & $\begin{array}{l}\text { After } \\
\text { Indomethacin } \\
10 \pm 2^{*} \\
12 \pm 2^{*}\end{array}$ \\
\hline
\end{tabular}

${ }^{*} p<0.05$ when compared with control.

after indomethacin, but potentiated neuromuscular blockade by succinylcholine an average of four per cent $(p>0.05)$ before and 12 per cent ( $p$ $<0.05$ ) after indomethacin (Table II)

\section{Discussion}

Our results show that the cat sciatic-tibialis preparation responded in a dose-related manner to the administration of d-tubocurarine or succinylcholine and the neuromuscular blocking actions were not influenced by prostaglandin synthetase inhibition. "Prostaglandin synthetase" is a multi-enzyme complex, apparently present in every mammalian tissue thus far investigated. ${ }^{2}$ "Aspirin-like drugs", although of diverse chemical structure, possess antipyretic, analgesic and anti-inflammatory activity in the decreasing order of potency: indomethacin > phenylbutazone $>$ aspirin or ibuprofen. ${ }^{2}$ Therefore, indomethacin was selected as the prototype of the prostaglandin synthetase inhibitors. Wilkerson and Glenn ${ }^{3}$ have previously demonstrated that, at the dosages used in this study, intravenous indomethacin $3 \mathrm{mg} \cdot \mathrm{kg}^{-1}$ intravenously will cause effective prostaglandin synthetase inhibition within $30 \mathrm{mi}-$ nutes of administration. Thus it seems that inhibition of prostaglandin biosynthesis alone does not alter the action of neuromuscular blocking agents,

However, the intra-arterial administration of exogenous prostaglandins $\mathrm{PGE}_{2}$ and $\mathrm{PGF}_{2 \text { alpha }}$ antagonized d-tubocurarine and potentiated succinylcholine neuromuscular blockade, although only the combination of $\mathrm{PGF}_{2 \text { alpha }}$ with $\mathrm{d}$ tubocurarine was statistically significant. These effects were greatly enhanced after indomethacin administration. These results would be compatible with increased neurotransmitter release at the neuromuscular junction induced by these two prostaglandins.

$\mathrm{PGE}_{1}$ and $\mathrm{PGE}_{2}$ have been reported to reduce adrenergic nerve terminal release of norepinephrine in the isolated rabbit heart, while $\mathrm{PGF}_{2}$ alpha does not. ${ }^{1.5}$ Jansson et al. ${ }^{6}$ have reported $\mathrm{PGE}_{1}$ to inhibit acetylcholine releasc in the ral phrenic nerve-diaphragm preparation. It seems apparent, then, that different classes of prostaglandins in different species may increase or decrease neurotransmitter release at nerve terminals in which either acetylcholine or norepinephrine is the neurotransmitter.

Many of the prostaglandins, in particular the $E$ series, influence the tissue levels of $3^{\prime}, 5^{\prime}$ AMP. ${ }^{7,8}$ It is currently thought that the E series prostaglandins activate membrane-bound adenyl cyclase activity, especially in myocardium, by stimulation of a receptor site other than the betaadrenergic receptor site; beta-blockade will not block this effect of the prostaglandins. ${ }^{8}$ Standaert, et al. ${ }^{10}$ recently demonstrated that activation of adenyl cyclase, inhibition of phosphodiesterase and/or dibutyryl cAMP administration, increased motor nerve terminal $3^{\prime}, 5^{\prime}$. AMP levels and increased neurotransmitter output in the cat. Prostaglandin $E_{1}$ produced similar effects. ${ }^{10}$ Therefore, it appears that increases in nerve terminal 3', 5'-AMP induced pharmacologically may increase neurotransmitter release. These reports by other investigators are compatible with the data presented here. $\mathrm{PGE}_{1}$ has been shown to have no effect on the response of skeletal muscle to acetylcholine, " further suggesting that the effects of the prostaglandins are on transmitter release at the nerve terminal.

Our data imply greater neurotransmitter release induced by $\mathrm{PGE}_{2}$ and $\mathrm{PGF}_{2 \text { alpha }}$ after prostaglandin synthetase inhibition. since an increase in acetylcholine concentration at the neuromuscular junction is expected to antagonize the nondepolarizing blockade of d-tubocurarine, but to potentiate the depolarizing blockade of succinylcholine. Samuelsson and Wennmalm ${ }^{12}$ similarly observed that prostaglandin synthetase inhibition augmented release of norepinephrine from the isolated rabbit heart during sympathetic nerve stimulation, suggesting a prostaglandin-mediated control mechanism at the adrenergic nerve terminal. Prostaglandins may also modulate neurotransmitter release at the neuromuscular junction. It is possible that indomethacin may promote 
acetylcholine release by inhibiting the synthesis of prostaglandins that normally limit neurotransmitter release.

\section{ACKNOWLEDGEMENTS}

We are grateful to Dr. John Pike of Upjohn Co. for generous supply of the $P G E_{2}$ and $P G F_{2}$ alpha.

\section{REFERENCES}

1. Hedquist, P. Basic mechanisms of prostaglandin action on autonomic neurotransmission. Ann. Rev. Pharmacol. Toxicol. 17: 259 (1977).

2. Flower, R.J. Drugs which inhibit prostaglandin biosynthesis. Pharmacol. Rev. 26: 33(1974).

3. Wilkerson, R.D. \& GLENN, T.M. Influence of non-steroidal anti-inflammatory drugs on ouabain toxicity. Am. Heart J. 94: 454 (1977).

4. Hill, G.E., WONG, K.C. \& Hodges, M.R. Lithium carbonate and neuromuscular blocking agents. Anesthesiology 46: 122(1977).

5. Hedouist, H. \& WENNMALM, A. Comparison of the effects of prostaglandins $E_{1}, E_{2}$ and $F_{2 \text { alpha }}$ on the sympathetically stimulated rabbit heart. Acta Physiol. Scand. 83: 156 (1971).

6. Jansson, S.E., Hyvarinen, J., Tolppanen, E.M., et al. Prostaglandin $\mathrm{E}_{1}$ on neuromuscular transmission. Acta Physiol. Scand. 91: 26. (1974).

7. Ten Hoor, F., \& Vergroesen. A.J. Prostaglandins and the heart. J. Mol. Cell. Cardiol. 7: 535 (1975).

8. Levey, G.S. \& KLeIN, I. Solubilize!l nyocardial adenylate cyclase: activation by pustaglandins. Life Sci. 13: 41 (1973).

9. KLeIN, I., \& LeVEY, G.S. Effect of prostaglandins on guinea pig myocardial adenyl cyclase. Metabolism 20: 890 (1973).

10. Standaert, F.G., Dretchen, K.L.. Skirboll, L.R., et al. A role of cyclic nucleotides in neuromuscular transmission. J. Pharm. Exp. Ther. 199: 533 (1976)

11. Fletcher. P. \& Forrester, T. The effect of curare on the release of acetylcholine from mammalian motor nerve terminals and an estimate of quantum content. J. Physiol. 251: 131 (1975).

12. Samuelsson. B. \& Wennmalm. A. Increased nerve stimulation induced release of noradrenaline from the rabbit heart after inhibition of prostaglandin synthesis. Acta Physiol. Scand. 83: 163(1971).

\section{RÉSUMÉ}

Les effets de l'inhibition de la biosynthèse des prostaglandines par l'indométhacine et les effets de l'injection artérielle de prostaglandines $E_{2}$ et $F_{2 a l s n a}$ avant et après l'inhibition de la biosynthèse des prostaglandines sur le bloquage neuromusculaire obtenu par la d-tubocurarine et la succinylcholine ont été étudiés sur la préparation sciatique-tibial du chat.

L'inhibition non spécifique de la biosynthèse prostaglandinique par l'indométhacine $3 \mathrm{mg} \cdot \mathrm{kg}^{-1} \mathrm{n}$ 'a pas modifié la période de latence. le sommet ou la durée du bloquage neuromusculaire provoqué par la d-tubocurarine ou la succinylcholine.

La prostaglandine $\mathrm{E}_{2}$ a antagonisé la dépression de l'amplitude de la secousse musculaire causée par la d-tubocurarine de 6 pour cent en moyenne avant et de 15 pour cent en moyenne après l'indométhacine, mais a potentialisé le bloc neuromusculaire de la succinylcholine par 5 pour cent en moyenne avant et par 60 pour cent en moyenne après l'indométhacine. La

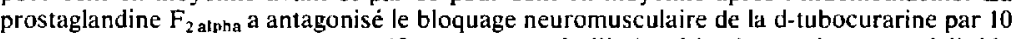
pour cent en moyenne avant et par 18 pour cent après l'indométhacine, mais a potentialisé le bloquage de la succinylcholine par 4 pour cent en moyenne avant et par 12 pour cent en moyenne après l'indométhacine.

Ces résultats semblent indiquer que l'inhibition non spécifique de la biosynthèse prostaglandinique seule n'a pas d'influence sur le bloquage neuromusculaire provoqué par la d-tubocurarine et la succinylcholine. Cependant, les prostaglandines $E_{2}$ et $F_{2}$ alpha peuvent provoquer une libération de médiateur à la jonction neuromusculaire possiblement accrue par l'indométhacine, ce qui aurait pour effet d'antagoniser le bloc non-dépolarisant de la d-tubocurarine et de potentialiser le bloc dépolarisant de la succinylcholine. 